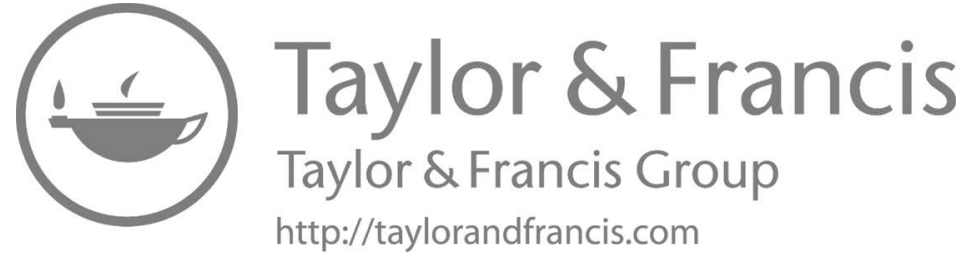




\title{
CHALLENGING THE CORDON SANITAIRE IN BELGIUM
}

\section{A diachronic analysis}

\author{
Benjamin Biard
}

\subsection{Introduction}

An increasing number of radical right populist parties (RRPPs) got closer to power in the last few decades (Biard, 2019a, 2019b; Jamin, 2016). In some cases, these parties support or have supported a minority government, such as in the Netherlands or Denmark. In other cases, they directly participate or have participated in government coalitions, such as in Austria, Bulgaria, Italy, Norway, Poland, Slovakia or Switzerland. Yet, Belgium remains an exception. Even though they have been a strong electoral and political force ever since the early 1990s, no RRPP has ever exercised power in Belgium, neither directly nor indirectly, from the local to the national level. This situation is particularly striking regarding Vlaams Belang (Flemish Interest, VB), which succeeded in becoming one of the dominant parties in Flanders (Rihoux et al., 2020). This paradox between electoral strength and the lack of government participation may be explained by the strategies adopted by mainstream parties toward RRPPs. In particular, the so-called cordon sanitaire, i.e. the deliberate decision of most mainstream parties not to govern with the VB, explain why RRPPs' electoral power has not translated into executive power.

The aim of this chapter is to take stock of the arguments used by mainstream parties to justify the cordon sanitaire and question how mainstream parties have dealt with RRPPs over the years. Our analysis suggests that Belgian mainstream parties are strongly defending the cordon sanitaire principle, based on three main types of arguments: value-based, ideology-based and association-based arguments. However, the chapter also indicates that the cordon sanitaire faces great challenges that lead to questions about the durability of the cordon sanitaire in Belgium over time and, more generally, the durability of disengagement strategies toward RRPPs. 
To this end, the chapter first defines the notion of radical right populism and proposes a state of the art of the mainstream parties' strategies adopted toward RRPPs. After some methodological considerations, the chapter develops the analysis based on a set of 36 interviews conducted with elected representatives and party officials and media archives. Finally, a discussion and some concluding remarks are formulated.

\subsection{Radical right populist parties (RRPPs) and mainstream parties' strategies toward them}

While Kitschelt (1997) wrote in 1997 that RRPPs were politically marginalized, RRPPs have since entered a new phase in their development. Today, they not only achieve significant electoral performance but they also manage to move ever closer to power. After all, in an increasing number of cases, they enter into a government and yield executive power, whether at the local, the regional or the national level. Moreover, recent research has shown that RRPPs in power are not necessarily doomed to failure since they are sometimes able to stay in power for several consecutive legislatures (Zaslove, 2012).

The literature has extensively studied the factors of RRPPs' success (e.g. Moffitt, 2016), the history of these parties (e.g. Betz, 2013), their leaders (e.g. Pappas, 2016), electorate (Norris, 2005) or policy influence (e.g. Biard, 2020) but scholars have paid less attention to the reactions of mainstream parties to RRPPs. Because these parties mobilize populism and defend a restrictive position on both immigration and law and order issues (Mudde, 2013), they are generally not considered to be 'classical parties'. As such, it would be interesting to study how mainstream parties' position themselves toward these RRPPs.

RRPPs are often considered a threat to liberal democracy (Rummens, 2017; Urbinati, 2014) because they disregard the separation of powers or the rights of minorities (Albertazzi \& Mueller, 2013). In spite of the perceived threat RRPPs represent, these parties perform well during elections at each level of government (Kriesi \& Pappas, 2015; Rensmann et al., 2017) and become able to - directly or indirectly - influence policymaking (Biard et al., 2019; Biard, 2021). Even if they do not access power or perform well in a general election, they also become a real electoral threat to mainstream parties, and particularly to right-wing mainstream parties (Bale, 2008; Van Kersbergen \& Krouwel, 2008), because of their anti-establishment stances. Therefore, mainstream parties tend to strategize against RRPPs.

Different political strategies toward RRPPs have been developed by mainstream parties (Grabow \& Hartleb, 2013; Meguid, 2005). These strategies might be explicitly adopted in reaction to the parties (such as by using legal tools in order to ban a party) and their ideas/policies (such as when mainstream parties co-opt RRPP policies). Mainstream parties can either engage or disengage with RRPPs (Downs, 2001) (Table 5.1). This means they can co-opt some of their policy proposals and collaborate with them, or they can ignore them, block coalitions and adopt legal restrictions (Downs, 2001; Heinze, 2018; Minkenberg, 2006). 
TABLE 5.1 Strategies of mainstream parties toward RRPPs (adapted from Downs, 2001; Heinze, 2018)

\begin{tabular}{ll}
\hline Disengage strategies & Engage strategies \\
\hline $\begin{array}{l}\text { Ignore RRPPs and their policies } \\
\text { Cordon sanitaire }\end{array}$ & Co-opt RRPPs' policies \\
Legal restrictions & Collaborate with RRPPs \\
\hline
\end{tabular}

With a 'disengage strategy', mainstream parties can first ignore RRPPs. By ignoring them, they wish to diminish their legitimacy, making them less attractive to voters (Downs, 2001). They can either ignore the parties themselves or the issues they raise and the positions they take on those issues. Second, they can establish a cordon sanitaire, which is an agreement between political parties to exclude any form of collaboration with a specific party (Jagers \& Walgrave, 2007). This means that mainstream parties refuse to govern with RRPPs, they refuse to form a minority government with the external support of an RRPP or they refuse to cooperate at the legislative level, for example by passing legislation thanks to the support of the RRPPs. Traditionally, a cordon sanitaire is decided concomitantly with the demonization of RRPPs (Taguieff, 2014). This demonization discourse helps to justify the cordon sanitaire by framing RRPPs as a threat to liberal democracy. Finally, they can enact legal restrictions against them to limit their power and influence. For instance, mainstream parties may ask for the suspension of the public funding of RRPPs (Cadranel \& Ludmer, 2008) or RRPPs' bans (Bale, 2007; Bourne \& Casal Bértoa, 2017).

The literature underlines that the electoral consequences of a disengagement strategy for RRPPs can be particularly important (Minkenberg, 2006). Such a strategy can indeed create an exhaustion effect for the RRPPs' electorate, leading it to vote for another party or abstain (Pauwels, 2011).

However, mainstream parties do not just disengage RRPPs. Since the end of the 1990s, the presence of RRPPs in Europe has gained acceptance (Widfeldt, 2010), and mainstream parties have increasingly adopted strategies of engagement toward them as a result. This means they collaborate with them by integrating them into the executive or gaining their support from outside (in the case of a minority government). This was or still is the case in Italy, the Netherlands, Denmark, Austria, Poland or Bulgaria. Beyond the fact that mainstream parties can collaborate with RRPPs, they can also be 'contaminated' by them (Norris, 2005: 266). This means mainstream parties can co-opt RRPPs' policies without collaborating with them. This contagion effect seems to affect parties in opposition more than parties in government (van Spanje, 2010). In addition, Han (2015: 571) has shown that mainstream parties "adjust their positions only when they feel an immediate and direct threat to their status in party competition".

Previous studies have also addressed the consequences of an engagement strategy toward RRPPs and suggest that this can diminish the confidence or 
hope of the RRPP electorate. Indeed, RRPPs traditionally have a weak bargaining position because of their extreme position on the left-right continuum (Akkerman \& de Lange, 2012). Therefore, such a strategy can also lead to an electoral decline for RRPPs. For instance, the integration of the Greek LAOS (Laikos Orthodoxos Synagermos) into the national government in 2011 provoked the electoral decline of the party and the development of another RRPP: Golden Dawn (Deleersnijder, 2016). Yet, an engagement strategy can also have consequences for mainstream parties, affecting their internal dynamics (Goodwin, 2011).

Research has shown that the strategies outlined previously are not unique and not static: several types of strategies can be adopted, and these strategies can evolve (Heinze, 2018). Yet, generally, mainstream parties tend to shift from a 'disengage strategy' toward an 'engage strategy'. They hardly ever shift from an 'engage strategy' toward a 'disengage strategy'. Mainstream parties can also engage with RRPPs for several reasons, including accessing power or adopting and fulfilling their own pledges for electoral purposes, in short, for office-seeking, policy-seeking and vote-seeking (De Lange, 2012). Mainstream parties thus carry out a cost-benefit analysis (van Heerden et al., 2014).

\subsection{Belgium: an atypical case}

From this state of the art, it is clear that mainstream parties have dealt with the cordon sanitaire in many ways. However, Belgium remains an exception in several regards when studying strategies adopted by mainstream parties toward RRPPs. First of all, Belgium is characterized by a split party system and Flemish RRPPs are different from Walloon RRPPs (Istasse, 2019; Pilet et al., 2009). Moreover, RRPPs have various electoral destinies in Belgium depending on the region in which they develop (Biard \& Faniel, 2019; De Jonge, 2020). While they achieve important electoral performances in Flanders, they are struggling to take off in Wallonia or Brussels. In Flanders, the VB - which is the most significant RRPP for several decades - indeed became the second largest party in the elections of 26 May 2019 (see Figure 5.1). ${ }^{1}$ On the contrary, Walloon RRPP such as the Front national (FN) or the Parti Populaire (PP) remained marginalized for a long time, before disappearing. For its part, Nation (which still exists) has always been marginal and has never succeeded in obtaining a seat in a parliamentary assembly (Dohet et al., 2014: 62-64). This is the reason why this chapter focuses on strategies adopted by mainstream parties toward the VB.

The Belgian case is also an exception with regard to the relationship between RRPP and power. Contrary to almost all other European countries, no Belgian radical right populist party has exercised executive power at any level over years, in spite of the fact that the VB performs particularly well in Flanders. It is a paradox that is maintained over time - even if the VB has been in significant decline for a period of ten years until $2019 .^{2}$ 


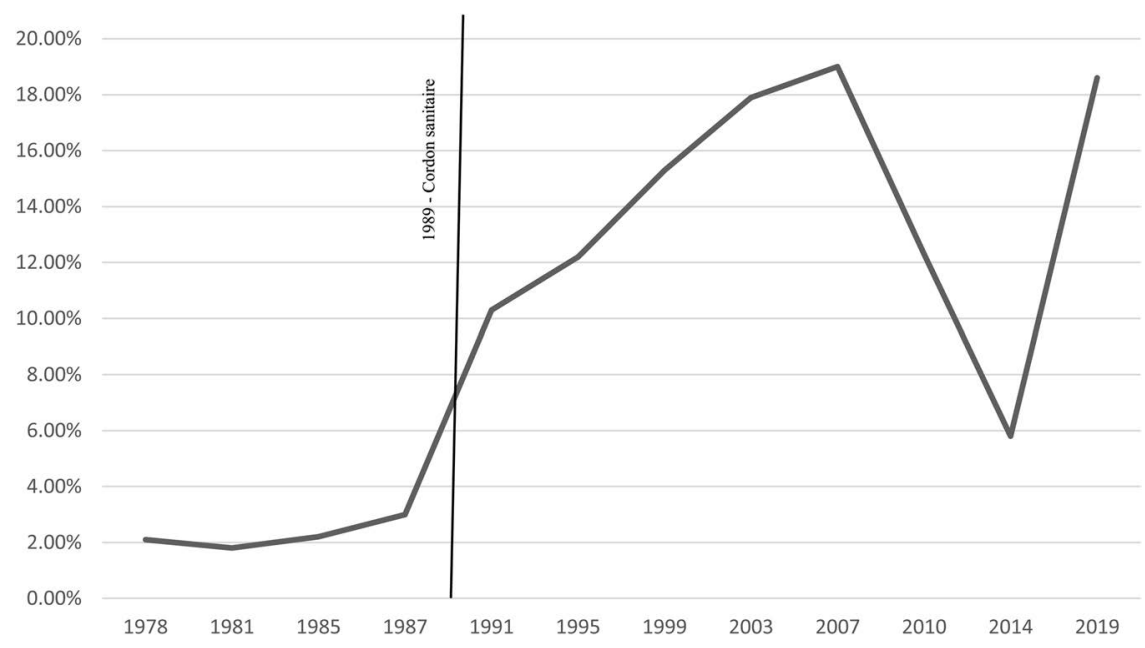

FIGURE 5.1 Results of Vlaams Belang in the federal elections (Flemish cantons) from 1978 to 2019

Such a paradox can be explained by the exceptionally high level of formalization of the cordon sanitaire in Belgium. Set up in the wake of the municipal elections of 9 October 1988, during which the Vlaams Blok (the previous name of the VB) made a significant electoral breakthrough, the cordon sanitaire was born in Belgium on 10 May 1989, on the initiative of Jos Geysels, Member of Parliament and National Secretary of the Dutch-speaking Green Party (Agalev). He urged all the mainstream parties to reject any alliance with the VB, at all levels of power. The protocol signed at that time specifies that:

The signatories commit their party not to enter into political agreements or commitments with the Vlaams Blok, either within the framework of democratically elected assemblies at municipal, provincial, regional, national and European level, or in the framework of elections at these same levels of power.

Even if several of its signatories quickly deny it, the cordon sanitaire will be concluded again between the Flemish parties and later between the French-speaking parties, especially after the elections of 24 November 1991, described as 'Black Sunday' as a consequence of the important electoral performances made by the VB. Based on the same text, the cordon sanitaire is deemed to have been maintained until today.

Even though the cordon sanitaire has been an active strategy in Belgium for over 30 years, very little is hitherto known about why mainstream parties support this strategy. Based on a qualitative method, this research aims at better understanding how mainstream parties have dealt with the cordon sanitaire over years. 
For this purpose, data are collected both through interviews conducted with 36 elected representatives and party officials between May 2017 and January 2018 and the collection of media archives. These data are then subject to a thematic analysis after categories and subcategories have been created (Miles et al., 2013). The latter make it possible, in particular, to distinguish three types of arguments relating to the willingness of political actors to maintain the cordon sanitaire.

\subsection{Empirical findings}

This section analyzes the extent to which the cordon sanitaire strategy is being maintained in Belgium, and what tensions the cordon sanitaire has been facing since its adoption. The ultimate goal of this section is to better apprehend how mainstream parties behave regarding RRPPs in Belgium, and particularly regarding VB (Section 5.4.1), and how their strategies have evolved over time (Section 5.4.2).

\subsubsection{The attitude of mainstream parties regarding VB today}

The absence of VB from power since its foundation in 1979 can be understood in the light of the cordon sanitaire strategy adopted by mainstream parties more than 30 years ago (Pauwels, 2011). Today, the cordon sanitaire still exists to prevent RRPPs from exercising power. The interviews we conducted highlight three major reasons why mainstream parties - not only from the north (Flemishspeaking; FL) but also from the south (French-speaking; FR) of the country adopt a disengage strategy toward RRPP, and particularly toward the VB.

First - and maybe the most important one - they deny any collaboration and even refuse to acknowledge the proposals made by RRPPs because they consider that the latter are a danger for liberal democracy. These are value-based arguments: mainstream parties refuse to engage with the policies proposed by VB because they believe these will a priori violate liberal democratic principles. It should be noted that one N-VA interviewee (cf. later) recognizes the importance of the cordon sanitaire because of the undemocratic nature of $\mathrm{VB}$, although this is not the official position of his party. For instance, another interviewee from the N-VA states, "in my opinion the cordon sanitaire is undemocratic" (N-VA MP [FL], interviewed 12 July 2017). All the positions of the interviewees from other parties reflect the official positions of the party to which they belong.

Alinea I am not familiar with these law proposals. I have not read them. (CDEV MP [FL], interviewed 13 June 2017)

We never vote on a text or amendment of the Vlaams Belang. And I don't speak with them. No contacts.

(Groen MP [FL], interviewed 6 July 2017) 
It is not a democratic party. And those who deny human rights in favor of a well-found but completely obscure rule like eigen volk eerst are not correct. And therefore I will not make any agreement with a party that, in my opinion, does not belong to democracy.

(N-VA MP [FL], interviewed 4 July 2017)

We have never worked with Vlaams Belang. The MR is a democratic party and Vlaams Belang has always been regarded by my party as unacceptable. So we have never... We don't discuss with them. So let's be clear. We greet them because we are polite, but that is all. So there is absolutely no contact, and certainly not on the substance of the subjects.

(MR MP [FR], interviewed 18 May 2017)

Our relations with Vlaams Belang are inexistant. We even do not say hello to each other's. I do not want any contact with Vlaams Belang. No contact, even no respect. It is an absolute principle. I do not pay any attention to their proposals.

(Défi MP [FR], interviewed 1 June 2017)

When they [Vlaams Belang's elected officials] propose something, it is an automatic reject. Because it comes from them. When we receive law proposals, my assistant provides me an analysis project by project. He says "that party proposes that, that other parties are against, etc.". However, when it comes to the proposals by Vlaams Belang he only says "no comment, we will vote against anyway". I thus even not receive the analysis by my assistant.

(PS MP [FR], interviewed 16 June 2017)

Second, mainstream parties claim that they often refuse any collaboration with VB because they consider that their ideas are globally too far from their own ideas. Support for the cordon sanitaire is thus also based on ideological concerns.

I have never voted for Vlaams Belang and I do not have any sympathy for that party. For me it has always been clear that I wanted to be involved first in the Volksunie and, later, in the NVA. I have never been attracted by the discourse of the Vlaams Belang. They are too provocative and too racist. They go too further.

(N-VA MP [FL], interviewed 15 September 2017)

Third, mainstream parties may agree with VB's proposal at some occasions or, to some extent, their ideas may converge. Yet, they are afraid to be associated with that RRPP if they defend a similar proposal. Therefore, on such occasions, they refuse to strive for the adoption of that proposal. It results from the fact that they fear electors' reactions. Nevertheless, that third option is usually found in 
right-wing or center-right political discourse, more than in left-wing political discourse. They believe that too close an association with VB might legitimize RRPPs claims or might be electorally disadvantageous. Such fears have already led to the exclusion of several representatives from their party, such as JeanMarie Dedecker or Hugo Coveliers from VLD (the previous name of the Open VLD) between 2004 and 2006. Globally, that third element thus has a less strong explanatory strength than the first since it concerns a smaller number of parties and elected representatives.

Alinea. It is clear that, in some cases, obtaining the support of a RRPP is problematic for the adoption of a text because we refuse, of course, any assimilation or comparison with them. Therefore if someone says "you know, the Vlaams Belang has the same position than you", it is negative for us and, in fine, for the text.

(MR MP [FR], interviewed 18 May 2017)

I think that if the Vlaams Belang proposes a text himself, it is an obstacle for us. We cannot defend a proposal made by that party. It is never a pleasure to admit that adopted measures come from the Vlaams Belang. The cordon sanitaire still exists.

(CDEV MP [FR], interviewed 8 June 2017)

In some cases, certain issues were never discussed externally precisely because they were carried by Vlaams Belang.

(CDH MP [FR], interviewed 29 June 2017)

If the Vlaams Belang addresses an interesting issue, it kills the issue. Even if it says the truth. We cannot be aligned to the Vlaams Belang because they are considered as lepers.

(previous LDD MP [FL], interviewed 25 July 2017)

The interviews demonstrate that these factors explain why mainstream parties still adopt disengage strategies toward VB. Even more, they ardently defend the cordon sanitaire principle. Among the parties represented in Parliament and apart from RRPPs, only the N-VA does not officially defend the maintenance of the cordon sanitaire, even if some of its elected representatives admit that they want it to be maintained. Three main types of rationales can be distinguished on the basis of the thematic analysis: value-based, ideology-based and association-based arguments.

\subsubsection{An ever-increasing challenge to the cordon sanitaire}

Despite overwhelming support for the cordon sanitaire, it has been put under pressure several times, particularly since the early 2000s and in Flanders. At that moment, the VB achieved what was then its best electoral performance, 
particularly on the occasion of the 2004 regional elections (with $24.0 \%$ of the votes in Flanders - which remains the best electoral result of its history). In 2004, the VB was also convicted by a court on the basis of the law aiming at punishing certain acts inspired by racism and xenophobia, as a result of which it decided to dissolve and refound itself based on an apparently more smooth and less radical discourse.

Four main kinds of pressures - which some consider to be real breaches of the cordon sanitaire - emerge from the qualitative analysis of the media corpus. These pressures are provoked by different actors, from various parties (including among those who officially support the cordon sanitaire), concerning different levels of power and intensify over time.

First, while the cordon sanitaire implies not only governing with RRPPs but also not passing laws with the support of these parties, some reforms would not have been possible without the contribution of VB's votes. For instance, it is the case with the adoption of the special law of 30 January 2004, modifying the size of the Flemish electoral districts for the renewal of the Flemish Parliament. On this occasion, a majority of two-thirds of the members of parliament was required. Despite the abstention of several members of the majority, the text managed to obtain a two-thirds majority and was adopted thanks to the indispensable support of both the N-VA and the VB. More recently, in December 2019, a VB law proposal was passed in the parliamentary Defense Committee, thanks to the support of N-VA and CD\&V. The law proposal considered requiring the Minister of Defense to append a report on the use of languages in the army to his annual policy note. This vote was made possible due to the absence of several MPs. Even if the law proposal was then rejected in a plenary session, on 19 December 2019, many observers and politicians consider this to be a break of the cordon sanitaire.

The second type of tension experienced by the cordon sanitaire relates to the formation of electoral alliances with the radical right populist party. In 2006 , in view of the local elections, VB entered into an alliance with another party for the first time. This led to the formation of a joint list between the VB and VLOTT (which was a splinter group of the VLD) in almost ten Flemish municipalities. Also in 2006, the VCD (which was a split from the CD\&V) also entered into a joint list with the VB in the municipality of Bree. Although these electoral alliances performed well in the areas where they run, the VB did not manage to join a coalition in any municipality. Moreover, the formations that formed an alliance with the VB are particularly marginal. No party with representation in a regional or federal parliamentary assembly ever constituted a joint list with the VB.

Third, several attempts to involve the VB in the formation of a government coalition have been made for more than 15 years. For example, following the regional elections of 13 June 2004 - in which the VB achieved a historically high score of $24.0 \%$ of the cast votes for the election of the Flemish Parliament the VB officials were invited by the informateur Yves Leterme (CD\&V) during 
his consultations in order to form a Flemish government. Although the aim of the meeting was more 'to respect VB voters' 3 than negotiate a real government agreement with the $\mathrm{VB}$, it marks an important turning point in the relationship between the VB and the largest party in Flanders (at that time in a cartel with the N-VA). Following the elections of 7 June 2009 and 25 May 2014, the VB officials were again consulted by the informateurs, namely Kris Peeters (CD\&V) and Bart De Wever (N-VA). However, any possibility of cooperation with the VB was quickly ruled out.

The breaking of the cordon sanitaire seemed most likely to occur in Flanders after the municipal elections of 14 October 2018. During this election, a local VB list (Forza Ninove), led by a Flemish MP and senator (VB), obtained 40.0\% of the votes (15 seats out of 33). The day after the election, Bart De Wever (the leader of the Right-wing N-VA) announced that he intended to examine internally the possibility of forming a coalition with Forza Ninove. However, De Wever quickly indicated "that the chances of a successful negotiation between Forza Ninove and the local N-VA, after seeing a racist photo circulated by the leader of Forza Ninove, were below zero". ${ }^{4}$ While the N-VA finally opted for the opposition, a coalition without the radical right list was finally formed. The cordon sanitaire was then maintained.

During the regional and community elections of 26 May 2019, the question of maintaining the cordon sanitaire reappeared. In the aftermath of these elections, the VB was invited to take part in several rounds of negotiations with the aim of forming a Flemish government. Although a coalition between the N-VA, CD\&V and Open VLD was eventually formed, a coalition involving the VB was actually considered. According to Gwendolyn Rutten - then president of the Open VLD - the N-VA explicitly proposed to the Open VLD and the CD\&V to govern together, with the VB. ${ }^{5}$ Although the liberal's statements are not confirmed within the N-VA, the fact remains that the break of the cordon sanitaire never seems to have been so imminent at the Flemish regional level.

Finally, more and more elected representatives or officials from mainstream parties are questioning the very idea of maintaining the cordon sanitaire. Beyond the N-VA that, officially, has never been in favor of maintaining the cordon sanitaire, several voices are indeed being raised within different mainstream parties to question it. For instance, on 5 June 2020, MP Hendrik Bogaert $(\mathrm{CD} \& \mathrm{~V})$ stated that it was time to get rid of the cordon sanitaire as a result of the electoral importance of extremes. According to him, allowing VB to participate in a coalition would be the best way to counter extremism: "When a party joins a coalition, it is obliged to bring nuances, to put water in its wine and to take others into account". 6 Such a discourse can also be found on the left of the political spectrum. On 30 August 2020, MP Melissa Depraetere (SP.A) indeed said, "For me, the cordon sanitaire should disappear; It is a stupid invention". ${ }^{7}$ Nevertheless, no party (beyond the N-VA) has officially questioned the very existence of the cordon sanitaire. 


\subsection{Conclusion}

Among the many available strategies to deal with RRPPs, Belgian mainstream parties have proven to be ardent advocates of disengagement through a cordon sanitaire. Even though this strategy has been in effect for over 30 years, the analysis indicates that support among mainstream parties remains strong for three reasons: most Belgian parties refuse any collaboration with VB because they consider that this RRPP is a threat for liberal democracy (value-based argument), because VB' ideas are too far from their own ideas (ideology-based argument) and because they are afraid to be associated with VB (associationbased argument).

However, despite the apparent support for the cordon sanitaire, our analysis has also shown that it is increasingly challenged in Flanders. Four types of challenges have been detected over time. First, some reforms have been made possible thanks to the contribution of VB's votes. Second, several electoral alliances with VB have emerged. Third, and most importantly, numerous and serious attempts to integrate VB within a coalition are multiplying. Finally, the very idea of maintaining the cordon sanitaire is increasingly questioned, despite the difficulties outlined earlier, both by right-wing and left-wing politicians.

Our analysis thus indicates that Belgium is at a nodal point: as long as the cordon sanitaire is being challenged, we can expect changes in the strategy adopted by mainstream parties toward RRPPs. The argument made by Heinze (2018) according to which mainstream parties tend to shift from a 'disengage strategy' toward an 'engage strategy' is thus not contradicted since the trend seems to be moving in that direction. The author indeed indicated that many Scandinavian parties not only increasingly adopt RRPPs' positions but also engage in collaboration with them over time. If this is not the case in Belgium today, the developments identified through the analysis suggest that this is a stage that could also be observed in Belgium in the next few years.

Moving forward, this chapter opens up a double research agenda. On the one hand, future research should be devoted, more broadly, to the analysis of engage and disengage strategies, with a specific focus on the co-optation of RRPPs' policies by mainstream parties in order to draw up a more complete picture of the evolution of the strategies adopted by mainstream parties toward RRPPs. This could be done by studying the evolution of parties' manifestos over time. Mainstream parties may indeed copy entire sections of RRPPs' manifestos for electoral purposes without, however, calling into question the very foundations of the cordon sanitaire. On the other hand, reactions to RRPPs not only come from mainstream parties but are also expressed through civil society (Lundberg, 2021). Yet, as underlined by Rovira Kaltwasser (2017), too little research has been done to better apprehend how civil society reacts to RRPPs and, more specifically, how their reactions evolve over time in Belgium. 


\section{Notes}

1 Born on the occasion of the national elections of 17 December 1978, the Vlaams Blok is an electoral cartel bringing together two parties (the Vlaams Nationale Partij and the Vlaamse Volkspartij). That cartel officially became a party in 1979.

2 In fact, the VB takes a positive turn in 2018, on the occasion of both the municipal and provincial elections. Cf. Blaise and Sägesser (2018) and Blaise et al. (2018).

3 La Libre Belgique, 17 June 2004.

4 RTBF INFO, 16 October 2018.

5 Le Soir, 26 June 2020.

6 De krant van West-Vlaanderen, 5 June 2020.

7 De Zondag, 30 August 2020.

\section{References}

Akkerman, T. \& De Lange, S. (2012). Radical Right Parties in Office: Incumbency Records and the Electoral Cost of Governing. Government and Opposition 47(4): 574-596.

Albertazzi,D. \& Mueller, S. (2013). Populism and Liberal Democracy: Populists in Government in Austria, Italy, Poland and Switzerland. Government and Opposition 48(3): 343-371.

Bale, T. (2007). Are Bans on Political Parties Bound to Turn Out Badly? A Comparative Investigation of Three 'Intolerant' Democracies: Turkey, Spain and Belgium. Comparative European Politics 5(2): 141-157.

Bale, T. (2008). Turning Round the Telescope. Centre-Right Parties and Immigration and Integration Policy in Europe. Journal of European Public Policy 15(3): 315-330.

Betz, H.-G. (2013). A Distant Mirror. Nineteenth-Century Populism, Nativism and Contemporary Right-Wing Radical Politics. Democracy and Security 9(3): 200-220.

Biard, B. (2019a). L'extrême droite en Europe occidentale (2004-2019). Courrier hebdomadaire $d u$ CRISP 2420-2421.

Biard, B. (2019b). L'extrême droite en Europe centrale et orientale (2004-2019). Courrier hebdomadaire du CRISP 2440-2441.

Biard, B. (2020). How Do Radical Right Populist Parties Influence Resurging Debates Over the Stripping of Citizenship? International Political Science Review 41(2): 224-237.

Biard, B. (2021). L'influence (in)visible. Les partis populistes de droite radicale et la fabrique de politiques publiques en démocratie. Bruxelles: Peter Lang.

Biard, B., Bernhard, L., Betz, H.-G. (2019). Do They Make a Difference? The Policy Influence of Radical Right Populist Parties in Western Europe. London: ECPR Press, Rowman \& Littlefield.

Biard, B. \& Faniel, J. (2019). L'extrême droite aux élections du 26 mai 2019: toujours ce paradoxe belge... Aide-Mémoire, juillet-août-septembre 2019: 6-7.

Blaise, P., Faniel, J. \& Istasse, C. (2018). Les résultats des élections provinciales du 14 octobre 2018. Courrier hebdomadaire du CRISP 2386-2387.

Blaise, P., Sägesser, C. (2018). Les résultats des élections communales du 14 octobre 2018 en Flandre. Courrier hebdomadaire du CRISP 2396-2397.

Bourne, A. \& Casal Bértoa, F. (2017). Mapping 'Militant Democracy':Variation in Party Ban Practices in European Democracies (1945-2015). European Constitutional Law Review 13(2): 224-247.

Cadranel, B. \& Ludmer, J. (2008). La législation concernant le financement des partis liberticides. Courrier hebdomadaire du CRISP 2001-2002.

De Jonge, L. (2020). The Curious Case of Belgium:Why is There no Right-Wing Populism in Wallonia? Government and Opposition Online First: 1-17. 
De Lange, S. (2012). New Alliances: Why Mainstream Parties Govern with Radical RightWing Populist Parties. Political Studies 60(4): 899-918.

Deleersnijder, H. (2016). Aube dorée et l'extrême droite en Grèce. In J.Jamin (Ed.), L'extrême droite en Europe. Bruxelles: Bruylant, pp. 79-90.

Dohet, J., Faniel, J., Govaerts, S., Istasse, C., Nassaux, J.-P., Wynants, J.-P. (2014). Les partis sans représentation parlementaire fédérale. Courrier hebdomadaire du CRISP 2206-2207.

Downs, W. (2001). Pariahs in Their Midst: Belgian and Norwegian Parties React to Extremist Threats. West European Politics 24(3): 23-42.

Goodwin, M. (2011). Right Response. Understanding and Countering Populist Extremism in Europe. London: Chatham House.

Grabow, K. \& Hartleb, F. (2013) (Eds.) Exposing the Demagogues. Right-Wing and National Populist Parties in Europe. Berlin: Konrad Adenauer Stiftung.

Han, K.J. (2015). The Impact of Radical Right-Wing Parties on the Positions of Mainstream Parties Regarding Multiculturalism. West European Politics 38(3): 557-576.

Heinze, A.S. (2018). Strategies of Mainstream Parties Towards Their Right-Wing Populist Challengers: Denmark, Norway, Sweden and Finland in comparison. West European Politics 41(2): 287-309.

Istasse, C. (2019). Les évolutions électorales des partis politiques (1944-2019) III. Les familles politiques. Courrier hebdomadaire du CRISP 2435.

Jagers, J. \& Walgrave S. (2007). Populism as Political Communication Style. European Journal of Political Research 46(3): 319-345.

Jamin, J. (2016) (Ed.). L'extrême droite en Europe. Bruxelles: Bruylant.

Kitschelt, H. (1997). The Radical Right in Western Europe. Ann Arbor, MI: University of Michigan Press.

Kriesi, H. \& Pappas, T. (2015). European Populism in the Shadow of the Great Recession. Colchester: ECPR Press.

Lundberg, E. (2021). Guardians of Democracy? On the Response of Civil Society Organisations to Right-Wing Extremism. Scandinavian Political Studies Online First: 1-25.

Meguid, B. (2005). Competition Between Unequals: The Role of Mainstream Party Strategy in Niche Party Success. American Political Science Review 99(3): 347-359.

Miles, M., Huberman, M. \& Saldana, J. (2013). Qualitative Data Analysis: A Methods Sourcebook. Los Angeles, CA: SAGE Publications Inc.

Minkenberg, M. (2006). Repression and Reaction: Militant Democracy and the Radical Right in Germany and France. Patterns of Prejudice 40(1): 25-44.

Moffitt, B. (2016). The Global Rise of Populism. Performance, Political Style and Representation. Stanford, CA: Stanford University Press.

Mudde, C. (2013). Three Decades of Populist Radical Right Parties in Western Europe: So What? European Journal of Political Research 52(1): 1-19.

Norris, P. (2005). Radical Right:Voters and Parties in the Electoral Market. Cambridge: Cambridge University Press.

Pappas, T. (2016). Are Populist Leaders 'Charismatic'? The Evidence from Europe. Constellations 23(3): 378-390.

Pauwels, T. (2011). Explaining the Strange Decline of the Populist Radical Right Vlaams Belang in Belgium:The Impact of Permanent Opposition. Acta Politica 46(1): 60-82.

Pilet, J.-B., De Waele, J.-M. \& Jaumain, S. (2009) (Eds.). L'absence de partis nationaux: menace ou opportunité? Bruxelles: Editions de l'Université de Bruxelles.

Rensmann, L., De Lange, S. \& Couperus, S. (2017). Editorial to the Issue on Populism and the Remarking of (Il)Liberal Democracy in Europe. Politics and Governance 5(4): 106-111. 


\section{Benjamin Biard}

Rihoux, B., Vandeleene, A., De Winter, L., Baudewyns, P. \& Deruette, S. (2020). Belgium: Political Development and Data in 2019. European Journal of Political Research Data Yearbook 59(1): 34-55.

Rovira Kaltwasser, C. (2017). Populism and the Question of How to Respond to It. In C. Rovira Kaltwasser, P. Taggart, P. Ochoa Espejo \& P. Ostiguy (Eds.), The Oxford Handbook of Populism. Oxford: Oxford University Press, pp. 554-570.

Rummens, S. (2017). Populism as a Threat to Liberal Democracy. In C. Rovira Kaltwasser, P. Taggart, P. Ochoa Espejo \& P. Ostiguy (Eds.), The Oxford Handbook of Populism. Oxford: Oxford University Press, pp. 554-570.

Taguieff, P.-A. (2014). Du diable en politique. Réflexion sur l'antilepénisme ordinaire. Paris: Ed. CNRS.

Urbinati, N. (2014). Democracy Disfigured. Opinion, Truth and the People. Cambridge, MA: Harvard University Press.

Van Heerden, S., De Lange, S.,Van der Brug,W. \& Fennema, M. (2014). The Immigration and Integration Debate in the Netherlands: Discursive and Programmatic Reactions to the Rise of Anti-immigration Parties. Journal of Ethnic and Migration Studies 40(1): 119-136.

Van Kersbergen, K. \& Krouwel, A. (2008). A Double-Edged Sword! The Dutch CentreRight and the Foreigners Issue. Journal of European Public Policy 15(3): 398-414.

Van Spanje, J. (2010). Contagious Parties: Anti-Immigration Parties and Their Impact on Other Parties' Immigration Stances in Contemporary Western Europe. Party Politics 16(5): 563-586.

Widfeldt, A. (2010). A Fourth Phase of the Extreme Right? Nordic Immigration-Critical Parties in a Comparative Context. Nordeuropa Forum 1-2: 7-31.

Zaslove, A. (2012). The Populist Radical Right in Government:The Structure and Agency of Success and Failure. Comparative European Politics 10(4): 421-448. 